\title{
ANALYSIS OF ANNUAL AND SEASONAL AIR TEMPERATURE TRENDS IN CENTRAL PART OF ROMANIA

\author{
Viorel Arghiuş ${ }^{1}$, Liviu-Octavian Muntean ${ }^{1 *}$, Nicolae Baciu ${ }^{1}$, \\ Vlad Măcicășan ${ }^{1}$, Corina Arghiuş ${ }^{2}$
}

\author{
Keywords: mean temperature, extreme temperature, trend, variability, \\ MAKESENS
}

\begin{abstract}
In the present study, the research was focused on analyzing long-term trends and variability of annual and seasonal air mean temperatures and some parameters related to cold and hot extreme temperatures, based on relevant continuous temperature data (1961-2018 period) provided by three regional weather stations (Cluj-Napoca, Deva and Miercurea-Ciuc). The Mann-Kendall test was used in order to find statistically-significant trends, while the magnitude of trends was estimated using Sen's slope estimator method. The main results showed a significant increase of mean air temperature, especially in the summer season and for indicators related to hot extreme temperatures. Generally, our findings are consistent with the current global warming and previous study results on temperature variability in Romania. Anyway by comparing our results with those from the other similar studies performed in Romania, it could be observed that the climate became warmer in the study area, so the trend in annual mean and seasonal air temperature has intensified and statistical significance of the results has significantly increased. Also, the intensification of the ,urban heat island" effect could be highlighted in the larger cities, like Cluj-Napoca. This increasing trend entails significant impacts on society, economy and natural ecosystems, which is expected to intensify in the near future.
\end{abstract}

\section{Introduction}

A lot of atmospheric processes, phenomena and natural hazards are closely linked to variability and trends of temperature. Rising air temperature may have different effects on different aspects of human life, especially on human settlements, agricultural products, energy consumption, etc. (Piticar \& Ristoiu,

1 "Babeş-Bolyai" University, Faculty of Environmental Science and Engineering, Cluj-Napoca, Romania; *Corresponding author email: liviu.muntean@ubbcluj.ro

2 "Gh. Lazăr"National Pedagogical College, 55 Al. Vaida Voevod Street, Cluj-Napoca, Romania 
2014). The changes that occur in temperature are important in understanding the general climate structure (Atilgan, et.al., 2017) and also for identifying the most suitable planning adaptation strategies in a given area (Marin, et.al., 2014). The significant rapid increasing in air temperature, particularly observed in last decades throughout the world is the most obvious evidence of climate change. The increase of mean temperature over the last century has been largely demonstrated and presented in many studies focused on different regions of the world (Croitoru and Piticar, 2014).

Based on the results of the 5th Climate Change Assessment Report prepared by the Intergovernmental Panel on Climate Change (IPCC, 2013) the global surface temperature data as calculated by a linear trend show a warming of $0.85^{\circ} \mathrm{C}$, over the period 1880 to 2012 . In the northern hemisphere, the 19832012 period was most likely the warmest 30 -year period of the last 1400 years, considering an average degree of confidence (IPPC, 2013, Arghiuș et al., 2017). According to existing data and studies, in the past 100 years, the average annual air temperature increased by $0.8^{\circ} \mathrm{C}$ in Romania (MEWS 2015), being consistent with the observed global and European warning pattern (Arghiuș, 2015). Therefore, in recent years, a lot of studies on climate change have focused on the trend analyses of the temperature parameters (Atilgan, et.al, 2017). In Romania, also, a lot of research studies on this topic have been carried out in the last years (Piticar and Ristoiu, 2012, Prăvălie, 2014, Piticar and Ristoiu, 2014, Marin et.al., 2014, Dumitrescu et.al., 2015, Bojariu, et.al., 2015, Bărbulescu and Deguenon, 2015, Arghiuș, et.al., 2015, Chitu., et.al., 2015, Arghiuș et.al., 2016, Machidon, 2017).

In this study, the research was focused on analyzing the trends and variability in the time series of air temperature parameters in the lower areas of central part of Romania, a historical region known as Transylvania. This kind of regional studies and also periodic updated temperature trend analysis could provide up-to-date valuable information for stakeholders in order to choose the most appropriate adaptation measures in the context of regional warming and changes in the derived-hazards, mostly in those related to water-cycle.

\section{Data and methodology}

Daily mean (TG), maximum (TX) and minimum (TN) air temperature data from three representative weather stations in the study region (Cluj-Napoca, Deva and Miercurea-Ciuc), covering a relevant period of 58 year-range (19612018), were used in order to perform this study (Figure 1). On January, 1961, the weather stations network in Romania was greatly reorganized and there were only few data missing from that point on, while the routine observation practices and timetable of the stations considered for this study have not 
changed until the end of the period (Croitoru and Piticar, 2014). The temperature daily data (blended time series version) were obtained through the European Climate Assessment \& Dataset (ECA\&D) platform (Klein Tank et al, 2002). The selected daily temperature raw data have been processed in order to obtain monthly, seasonal and annual mean temperature and some indicators related to cold and hot extreme temperatures.

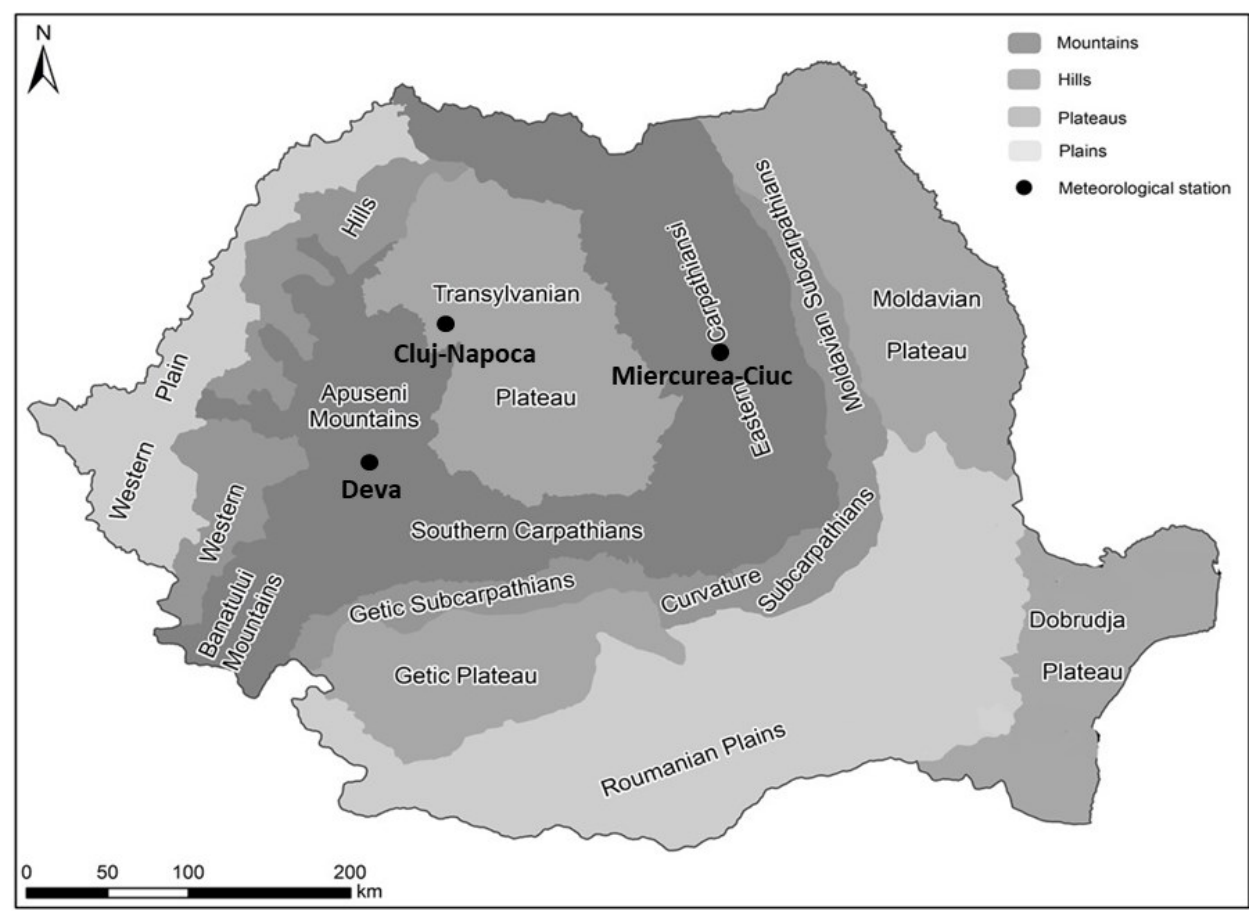

Figure 1. The location of the selected weather stations

The research methodology followed the next steps:

- analysing daily data in order to detect any inhomogeneity and errors;

- computing monthly, seasonal and annual mean air temperatures and parameters related to cold and hot extreme temperatures;

- achieving trend graphs by using Microsoft Excel;

- applying MAKESENS methodology (Mann-Kendall test for trend and Sen's slope estimator).

The MAKESENS is a non-parametric statistical method that facilitates trend determination in the data series (Atilgan et al., 2017). The Mann-Kendall test is applicable to the detection of a monotonic trend of a time series with no 
seasonal or other cycle. The Sen's method uses a linear model for the trend. These methods offer many advantages: missing values are allowed and data needed do not have to follow any particular distribution. In addition, single data errors of outliers do not significantly affect Sen's method (Salmi et.al, 2002). The purpose of the conditional Mann-Kendall test use is to check whether the trend in the time series of a dependent variable is statistically determined by the trend in the time series of the covariates (Piticar and Ristoiu, 2014). These methods, which are used here in their basic forms, are widely used to detect changes in climatic data series because it is robust to outliers and does not assume an underlying probability distribution of the data series (Moberg et al., 2002, cited by Croitoru and Piticar, 2014).

Mann-Kendall test was applied to 9 time series (annual and seasonal mean air temperature and 4 parameters relating to cold and hot extreme temperatures), corresponding to each of three weather stations. In our study, three significance levels are used $(0.05,0.01$, and 0.001$)$, considering the trends statistically significant when $\alpha \leq 0.05$ (95\% confidence level).

\section{Results and discussions}

\subsection{Annual and seasonal air temperature trends}

The results obtained by applying the MAKESENS methodology show that annual and seasonal mean air temperature highlights a significant increasing trend in the study area.

Regarding annual mean air temperature at all weather stations a statistically significant increasing trend (0.001 level) can be noticed (Table 1, Figure 2), while the temperature increasing gradient range between $0.27-0.40{ }^{\circ} \mathrm{C} / \mathrm{decade}$. Similar to the global trend, the high increasing rates are related to the warming acceleration process which can be observed in the late 80 s and especially in the last years as shown in the Figure 2.

Although the air temperature is significantly increasing all over the Romania, there are some places that have been affected more than others. A particular case is the one associated with the Cluj-Napoca weather station, where the temperature trend line shows a stepper slope compared to the other selected stations. This is an explainable situation considering the close connection between steeper warming and the effect of the non-climatic factor like topographic surfaces (Hasler et al., 2015), mainly by transformation of the natural landscape in the big city (Subarna, 2017). Specifically, this could be attributed to the rapid growth of built-up areas and building density in the last years over a large territory around this old weather station. Only in terms of housing, the official statistics data show that over 40,000 houses were built between 2006-2018 in Cluj Napoca city and close-surrounding localities (Florești, Baciu, Apahida, Chinteni 
villages), mainly in Florești village (about 20,000 houses). On the other hand the localities to which the other stations belong (i.e. Deva and Miercurea-Ciuc) are much smaller in terms of inhabitants and also increasing of the areas affected by the construction was significantly lower. So, there are clear evidences that the temperatures in Cluj-Napoca is influenced by the effect of „urban heat island” and it can be simply demonstrated by comparing the summer temperature trend data at all stations, prior to 2006 and after this time frame (Table 2). The reason for the summer season selection is obvious in this context, because the „urban heat island" effect is most clearly expressed in this season.

Table 1. Trends in annual and seasonal mean air temperature (1961-2018)

\begin{tabular}{|c|c|c|c|c|c|c|}
\hline Weather station & \multirow{2}{*}{$\begin{array}{c}\text { Altitude } \\
\text { (m a.s.1.) }\end{array}$} & \multicolumn{5}{|c|}{ Temperature trend slope $(1961-2018)\left({ }^{\circ} \mathrm{C} /\right.$ decade) } \\
\cline { 3 - 7 } & 410 & annual & spring & summer & autumn & winter \\
\hline Cluj-Napoca & 231 & $0.32 * * *$ & $0.38^{* * *}$ & $0.52 * * *$ & $0.25 *$ & $0.43 * * *$ \\
\hline Deva & 661 & $0.27 * * *$ & $0.27 * *$ & $0.47 * * *$ & $0.19 *$ & $0.35^{* *}$ \\
\hline Miercurea-Ciuc & $6.39^{*}$ & 0.13 & $0.29 *$ \\
\hline
\end{tabular}

Note: “*”, “**” and “***” indicate significance at $\alpha=0.05,0.01$ and 0.001 level

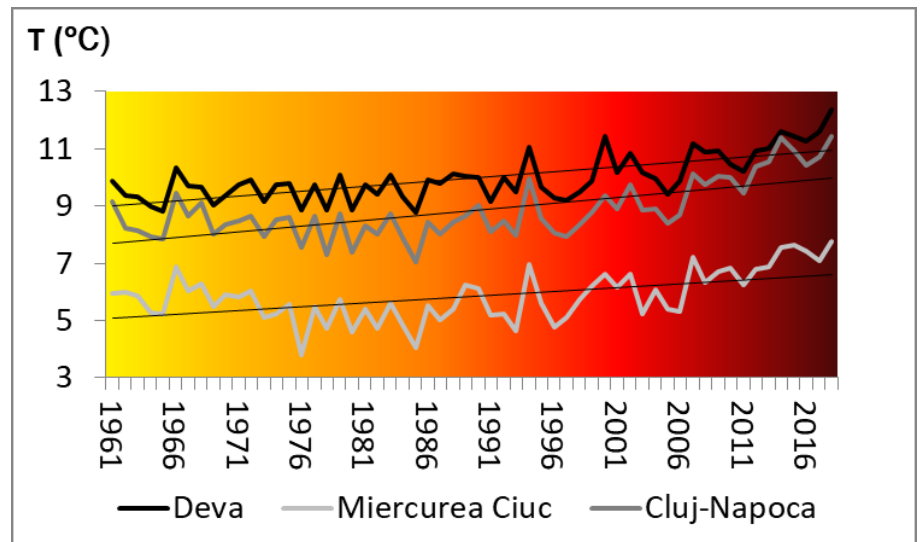

Figure 2. Graph showing the trends in annual mean air temperature (1961-2018)

Table 2. Comparative data regarding summer temperature trend

\begin{tabular}{|c|c|c|}
\hline \multirow{2}{*}{ Weather station } & \multicolumn{2}{|c|}{$\begin{array}{c}\text { Summer temperature trend slope (1961-2018) } \\
\left({ }^{\circ} \mathrm{C} / \text { decade) }\right.\end{array}$} \\
\cline { 2 - 3 } & $1961-2006$ & $1961-2018$ \\
\hline Cluj-Napoca & 0.19 & $0.52^{* * *}$ \\
\hline Deva & $0.23^{* *}$ & $0.47^{* * *}$ \\
\hline Miercurea-Ciuc & $0.20^{*}$ & $0.39^{* * *}$ \\
\hline Note: “*”, “**” and “***” indicate significance at $\alpha=0.05,0.01$ and 0.001 level
\end{tabular}


Seasonally, Sen's slope estimator indicated the highest positive slope of the trend line in case of the summer season $\left(0.39-0.52^{\circ} \mathrm{C} / \mathrm{decade}\right)$, with statistically significant level at 0.001 at all weather stations (Figure 3). A relevant warming has been also identified in spring $\left(0.22-0.38{ }^{\circ} \mathrm{C} /\right.$ decade). Also in winter, all stations recorded trends with stronger gradients than in the spring season $(0.29-$ $0.43{ }^{\circ} \mathrm{C} /$ decade), but with lower statistical significance. Positive slopes also prevail in the case of autumn, but highlight only a slightly increasing slope and in some cases are statistically insignificant (i.e. Miercurea-Ciuc) (Figure 3).
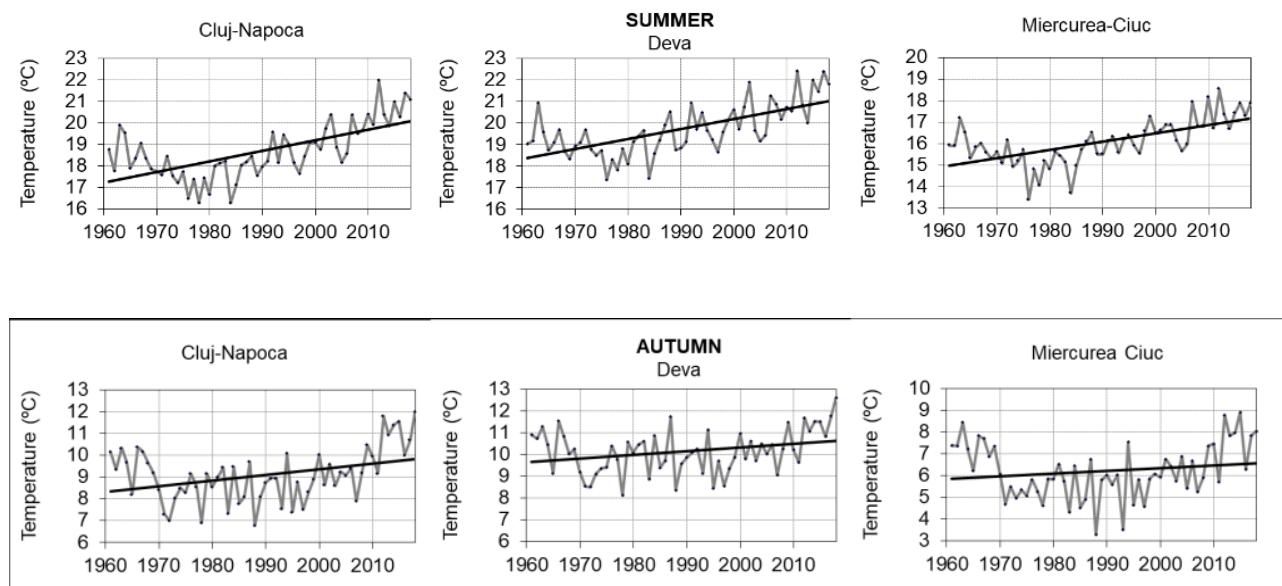

Figure 3. Graph showing the trends in seasonal mean air temperature (1961-2018)

\subsection{Hot and cold extreme temperature indicators}

In order to perform an in-depth analysis of temperature trends, it was also the most common parameters related to hot and cold extreme temperatures based on fixed thresholds (summer, tropical, frost and severe frost days). During the last decade, these indicators were widely used to assess climate changes of the extreme temperature for different regions of the world (Croitoru and Ristoiu, 2014).

Following the data from Table 3 and Figure 4, it can be observed that there is a clear evidence of climate warming. So the summer characteristic days has increase at all stations, while those characteristic to the cold season have had a downward trend. Anyway, the statistically significance is higher to those related to summer season, where throughout a positive trend line slope with statistically significant level at 0.001 it was noticed.

It is worth noting again the results obtained for the Cluj-Napoca station, where for all the analyzed parameters were reported trends with very high and 
high level of significance, highlighting once again the effect of the ,urban heat island".

Table 3. Trends in hot and cold extreme temperature indicators (1961-2018)

\begin{tabular}{|c|c|c|c|c|c|}
\hline \multirow{3}{*}{$\begin{array}{l}\text { Weather } \\
\text { station }\end{array}$} & \multirow{3}{*}{$\begin{array}{l}\text { Altitude } \\
\text { (m a.s.1.) }\end{array}$} & \multicolumn{4}{|c|}{ Trend slope (1961-2018) (no./decade) } \\
\hline & & \multicolumn{2}{|c|}{$\begin{array}{l}\text { Hot extreme temperature } \\
\text { indicators }\end{array}$} & \multicolumn{2}{|c|}{$\begin{array}{c}\text { Cold extreme } \\
\text { temperature indicators }\end{array}$} \\
\hline & & $\begin{array}{c}\text { Summer } \\
\text { days } \\
\left(\mathrm{TX} \geq 25^{\circ} \mathrm{C}\right)\end{array}$ & $\begin{array}{c}\text { Tropical } \\
\text { days } \\
\left(\mathrm{TX} \geq 30{ }^{\circ} \mathrm{C}\right)\end{array}$ & $\begin{array}{c}\begin{array}{c}\text { Frost } \\
\text { days } \\
\left(\mathrm{TN} \leq 0^{\circ} \mathrm{C}\right)\end{array} \\
\end{array}$ & $\begin{array}{c}\text { Severe frost } \\
\text { days } \\
\left(\mathrm{TN} \leq-10^{\circ} \mathrm{C}\right)\end{array}$ \\
\hline Cluj-Napoca & 410 & $5.88 * * *$ & $3.33 * * *$ & $-4.10 * *$ & $-2.31 * *$ \\
\hline Deva & 231 & $5.33 * * *$ & $4.59 * * *$ & $-4.14 * *$ & -0.91 \\
\hline $\begin{array}{l}\text { Miercurea- } \\
\text { Ciuc }\end{array}$ & 661 & $5.60 * * *$ & $1.25 * * *$ & -0.43 & -0.79 \\
\hline
\end{tabular}

Cluj-Napoca - tropical days

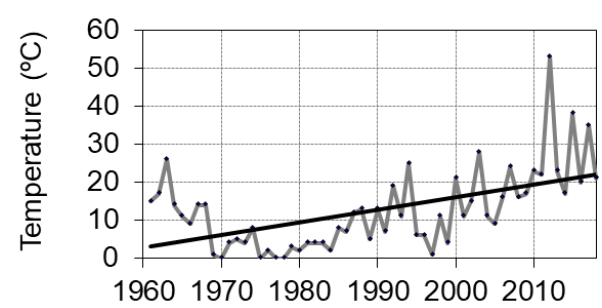

Cluj-Napoca - frost days

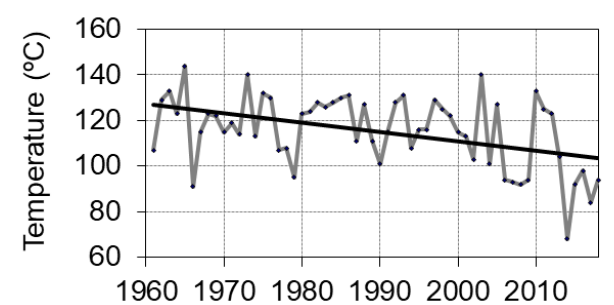

Cluj-Napoca - summer days

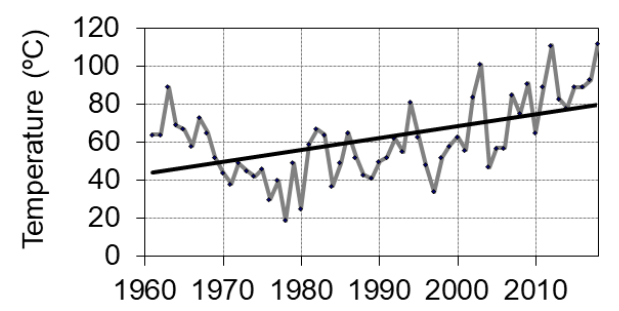

Cluj-Napoca - severe frost days

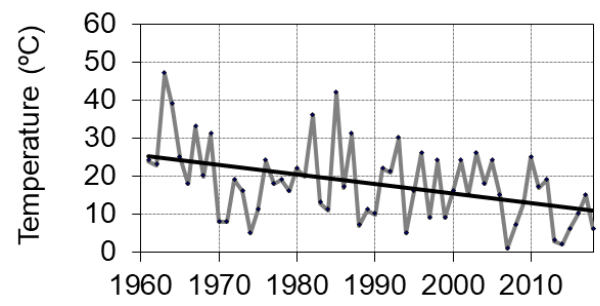

Figure 4. Graph showing the trends in hot (top) and cold (bottom) extreme parameters (Cluj-Napoca, 1961-2018)

Beside the general pattern of annual and seasonal trends are consistent with those reported in other studies for this region (Croitoru and Piticar, 2014, Arghiuș, et.al., 2015) and other part of Romania, trends with higher significance 
levels can be highlighted. Also could be observed that the climate became warmer in the study area, so the trend in annual mean and seasonal air temperature has intensified, including in autumn season, that doesn't indicate clear trends in the past studies.

\section{Conclusions}

Generally, our up-to-date findings are consistent with other similar studies on temperature trends performed across Romania. Thus, the annual air temperature presents significant increasing trends at all stations. The most important increase in the mean seasonal air temperature has proven to be in the summer season. Anyway by comparing our results with those similar from the other studies from Romania, it could be observed that the climate became warmer in the study area, so the trend in annual mean and seasonal air temperature has intensified and statistical significance of the results has significantly increased. Also, the intensification of the „urban heat island" effect could be highlighted in the larger city, like Cluj-Napoca. This kind of studies and also periodic updated temperature trend analysis could provide upto-date valuable information for stakeholders in order to choose the most appropriate adaptation measures in the context of global and regional warming.

\section{References}

1. Arghiuş V., Muntean L., Arghiuş C., Roşian G., Mihăiescu R., Baciu N., Maloş C., Măcicăşan V., (2015), Annual and seasonal air temperature and precipitation trends in the North of the Apuseni Mountains, ECOTERRA - Journal of Environmental Research and Protection, Romania, vol. 12/issue 4, 38-44. http://www.ecoterra-online.ro/files/1456067726.pdf

2. Arghiuş, V., Roşian, G, Mihăiescu, R., Muntean, O. L., (2016), Analysis of annual and seasonal air temperature and precipitation trends in south-eastern part of Romania in the context of climate change and desertification, SGEM International Multidisciplinary Scientific GeoConference, SGEM Conference Proceedings, DOI: 10.5593/SGEM_GeoConference, 227-235.

3. Arghiuş V., Ajtai, N., Ștefănie, H.,Arghiuş, C., (2017), The assessement of the risk induced by climatic changes on wastewater systems from Cluj county and the associated adaptation measures, Risks and disasters, Romania, 21, no. 2/2017, 6172.https://www.researchgate.net/profile/Nicolae Ajtai/publication/322645306 Th e Assessment of the Risk Induced by Climatic Changes on Wastewater Syst ems from Cluj County and the Associated Adaptation Measures/links/5ac203 
d3aca27222c75bc43e/The-Assessment-of-the-Risk-Induced-by-Climatic-Changeson-Wastewater-Systems-from-Cluj-County-and-the-Associated-AdaptationMeasures.pdf

4. Atilgan, A., Tanriverdi, C., Yucel, A., Oz, H., Degirmenci, H., (2017), Analysis of long-term temperature data using Mann-Kendall trend test and linear regression methods: The case of the Southeastern Anatolia Region, Scientific Papers, Series A, Agronomy, Vol. LX, 455-462. http://agronomyjournal.usamv.ro/pdf/2017/Art75.pdf

5. Bărbulescu A., Deguenon J., (2015), About the variations of precipitation and temperature evolution in the Romanian Black Sea littoral, Romanian Reports in Physics, Atmosphere Physics, Romania, vol. 67, no. 2, 625-637. http://rrp.infim.ro/2015_67_2/A30.pdf

6. Bojariu J., Bîrsan V.M., Cică R., Velea L., Burcea S., Dumitrescu A., Dascălu I.S., Gothard M., Dobrinescu A., Cărbunaru F., Marin L., (2015), The climatic change - from the phisical bases to risks and adaptation, Romania's National Meteorology Administration (ANM), PRINTECH Publishing house, Romania, 200 p, (published in Romanian)

7. Chitu, E., Giosanu, D., Mateescu, E., (2015), The Variability of Seasonal and Annual Extreme Temperature Trends of the Latest Three Decades in Romania, Agriculture and Agricultural Science Procedia 6, 429 - 437. https://doi.org/10.1016/j.aaspro.2015.08.113

8. Croitoru, A.E., Piticar, A., (2014), Changes in hot extreme temperature indices in Carpathian and intra-Carpathian areas of Romania, SGEM International Multidisciplinary Scientific GeoConference, SGEM Conference Proceedings, DOI:10.5593/SGEM2014/B42/S19.040.

9. Dumitrescu A., Bojariu R., Birsan M. V., (2015), Recent climatic changes in Romania from observational data (1961-2013), Theoretical and Applied Climatology, Vienna, Austria, vol. 122/issue 1, 111-119. https://doi.org/10.1007/s00704-014-1290-0

10. ECA\&D (European Climate Assessment \& Dataset) project, Meteorological data, 1961-2018 period.

11. IPCC (Intergovernmental Panel on Climate Change), (2013), Climatic Change: The Physical Science Basis, Contribution of Working Group I to the Fifth Assessment Report of the Intergovernmental Panel on Climate Change [Stocker, T.F., D. Qin, G.-K. Plattner, M. Tignor, S.K. Allen, J. Boschung, A. Nauels, Y. Xia, V. Bex and P.M. Midgley (eds.)]. Cambridge University Press, Cambridge, United Kingdom and New York, NY, U.S.A. 
12. Klein Tank, A. M. G., Wijngaard, J. B., Konnen, G. P., Bohm, R., Demarée, G., Gocheva, A., Mileta, M., Pashiardis, S., Hejkrlik, L., Kern-Hansen, C., Heino, R., Bessemoulin, P., Muller-Westermeier, G., Tzanakou, M., Szalai, S., Palsdottir, T., Fitzgerald, D., Rubin, S., Capaldo, M., Maugeri, M., Leitass, A., Bukantis, A., Aberfeld, R., Van Engelen, A. F. V., Forland, E., Mietus, M., Coelho, F., Mares, C., Razuvaev, V., Nieplova, E., Cegnar, T., Antonio Lopez, J., Dahlstrom, B., Moberg, A., Kirchhofer, W., Ceylan, A., Pachaliuk, O., Alexander, L.V. \& Petrovic, P., (2002), Daily dataset of 20th-century surface air temperature and precipitation series for the European Climate Assessment. Int. J. of Climatol., 22, 1441-1453, http://eca.knmi.nl

13. Machidon, O., (2017), The winter trends in air temperature and atmospheric precipitation in the Moldova Region (Romania), Present Environment and Sustainable Development, 11, 183 - 193. DOI 10.1515/pesd-2017-0017

14. Marin L., Bîrsan V.M., Bojariu R., Dumitrescu A., Micu M.D., Manea A., (2014), An overview of annual climatic changes in Romania: Trends in air temperature, precipitation, sunshine hours, cloud cover, relative humidity and wind speed during the 1961-2013 period, Carpathian Journal of Earth and Environmental Sciences, Romania, vol. 9, no. 4, 53-258.

15. MEWS, (2015), National Strategy on Climate Change and Economic Growth based on Low Carbon Emissions. Version for public consultation, September 2015, Ministry of Environment, Waters and Forests (MEWS), $150 \mathrm{p}$.

16. Moberg A., Jones P.D., Lister D., Walther A., Brunet M., Jacobeit J., Alexander L.V., Della-Marta P.M., Luterbacher J., Yiou P., Chen D., Klein Tank A.M.G. et al, (2002), Indices for daily temperature and precipitation extremes in Europe analyzed for the period 1901-2000, Journal of Geophysical Research, vol. 111, 125.

17. Piticar A., Ristoiu D., (2012), Analysis of air temperature evolution in Northeastern Romania and evidence of warming trend, Carpathian Journal of Earth and Environmental Sciences, Romania, vol. 7, no. 4, 97-106.

18. Piticar A., Ristoiu D., (2014), The influence of changes in teleconnection pattern trends on temperature and precipitation trends in Northeastern Romania, Risks and disasters, Romania, XIII, vol. 14, no. 1/2014, 109-122.

19. Prăvălie R., (2014), Analysis of temperature, precipitation and potential evapotranspiration trends in Southern Oltenia in the context of climate change, Geographia Technica, Romania, vol. 9/issue 2, 68- 84.

20. Salmi T., Maatta A., Anttila P., Ruoho-Airola T., Amnell T., (2002), Detecting trends of annual values of atmospheric pollutants by the Mann-Kendall test and 
Sen's slope estimates - the excel template application Makesens, Publications on Air Quality, 31, Finnish Meteorological Institute, Helsinki, Finland, 35 p.

21. Subarna, D., (2017), Analysis of Long-Term Temperature Trend as an Urban Climate Change Indicator, Forum Geografi, 31(2), 196-208.

C 2020 by the authors. Licensee UAIC, Iasi, Romania. This article is an open access article distributed under the terms and conditions of the Creative Commons Attribution (CC BY-NC-ND) license (https:// creativecommons.org/licenses/by-nc-nd/4.0). 